\title{
Behaviour of Strip Footing in the Vicinity of Non-Yielding Wall
}

\author{
Majid Touqan', Magdi El-Emam² \\ ${ }^{1}$ Graduate Student, Department of Civil and Environmental Engineering, the University of Western Ontario \\ London, Canada \\ mkhtouqa@uwo.ca \\ ${ }^{2}$ Associate Professor, Department of Civil Engineering, American University of Sharjah \\ Sharjah, United Arab Emirates \\ melemam@aus.edu
}

\begin{abstract}
The paper presents two-1/3 scale nonyielding wall-strip footing models that were constructed and tested at the sand box test facility at the American University of Sharjah (AUS). The objective of the testing program is to quantify the responses of both strip footing and nonyielding wall constructed closer to each other. To achieve this objective, different design construction parameters have been considered including: (1) the strip footing width (B), (2) footing distance from non-yielding wall back (a), and, (3) strip footing embedment depth below the backfill surface $\left(\mathrm{D}_{\mathrm{f}}\right)$. Test results indicated that the location of the strip footing relative to the wall is a major factor in dictating the load bearing capacity of the strip footing, and the maximum lateral deflection of the non-yielding wall. Meanwhile, the vertically loaded strip footing imposed substantial vertical and horizontal forces at the wall top and bottom boundaries. The strip footing load bearing capacity increased as the distance from the wall increased, the footing width decreased, and the embedment depth increased. Data collected from the responses of scaled-physical model test were used to recognize deficiencies in current design approaches for similar soil structure interaction problems.
\end{abstract}

Keywords: Strip Footing, Nonyielding Wall, Bearing Capacity, Lateral Force, Shallow Foundation, Sand.

\section{Introduction}

In metropolitan areas, underground basement can be considered as a practical solution for limited parking and storage areas. This is a feasible solution to keep the problem of the exponential increase of car numbers under control. Consequently, chances of constructing new buildings with shallow foundation neighbouring current buildings with basement walls are very high, in both residential and commercial areas. The proximity of shallow foundation of new structure to existing building may cause extra stresses to be created on the soil layers beneath the existing building. The additional exerted stress is expected to cause a reduction in the bearing capacity factor of safety used for the foundation design of the existing facility. Furthermore, the construction of new shallow foundation adjacent to basement wall is expected to impose additional lateral earth pressure, and deflection. The lateral deflection of basement wall my lead to a reduction of the bearing capacity of the closer shallow foundation. Therefore, this problem needs to be solved interactively. For this reason, an experimental program was developed and tested in AUS to study the behaviour of strip footing adjacent to nonyielding wall.

Lateral earth pressure on nonyielding walls is usually calculated using at lateral rest earth pressure theory proposed in literature [1, 2, 3, 4]. El-Emam [5] has experimentally confirmed that, for heavily compacted sand many of these theories are in fact unsatisfactory. Furthermore, such earth pressure theories neglect the effect of the presence of shallow foundation adjacent to nonyielding walls. Berg [6] conducted a small-scale model tests to examine the effect of surcharge loading on earth retaining walls. The main objective was the calibration of FEA models for the at rest earth pressure condition. Berg's [6] FEM results confirmed well with experimental responses. El-Emam [5] simulated non-yielding retaining wall system with uniformly graded sand backfill, in order to measure the horizontal force acting on the wall. In addition, he measured the vertical force exerted at the bottom of the wall both at toe and heel. Results of El-Emam [5] indicated that the measured horizontal earth force is about three times the value calculated by classical at-rest earth pressure theory. In addition, the location of the resultant earth force is located closer to $0.4 \mathrm{H}$, which is higher compared to the theoretical value of $\mathrm{H} / 3$. ElEmam [5] attributed this difference to the over consolidated degree of highly compacted sand. 
Rehnman and Broms [7] conducted a series of full scale model tests of reinforced concrete retaining walls to investigate the compaction induced stresses. In the experimental models two types of backfill were used; gravelly sand and silty fine sand. The loading of the experimental models simulated the application of wheel loads as surcharge of a pair of wheels with $2 \mathrm{~m}$ apart, 7.5-ton loads and $1 \mathrm{~m}$ away from the wall. Results showed that the measured peak pressure increased during loading, and the residual pressure increased after removal of point surcharge load. Dave and Dasaka [8] examined both magnitude and distribution of at-earth pressure with reference to wall movements of a rigid cantilever retaining wall. The results showed that the earth pressure due to surcharge loading was greater near the top of the wall and decreased nonlinearly down the wall. Finally, Dave and Dasaka [8] concluded that Jaky's [1] equation underestimates the earth pressure up to the mid height of wall, and overestimates it in the remaining section of the wall with depth. Results showed that as the distance between surcharge and wall increases, its effect on earth pressure reduces. Fang et al. [9] conducted experimental models where a strip footing was placed at distances away from the wall a $=0.15 \mathrm{~m}, 0.20 \mathrm{~m}, 0.40 \mathrm{~m}$. It was found out that the experimental lateral soil force induced by surcharge loading was apparently smaller than the theoretical predicted value. In addition, they reported that Jaky's [1] solution underestimated the lateral earth pressure in the compaction influenced zones near the top of the wall that have experienced high pressures due to compaction.

In this paper, results of two reduced-scale wall-strip footing model testes, model 5 with footing width $\mathrm{B}=20 \mathrm{~cm}$ at $\mathrm{a}=$ $3 \mathrm{~B}(60 \mathrm{~cm})$ and model 6 footing width $\mathrm{B}=15 \mathrm{~cm} \mathrm{a}=3 \mathrm{~B}(60 \mathrm{~cm})$ are reported. The focus of the paper is on the quantitative effect of the footing on the wall responses and the strip footing load carrying capacity and settlement. The strip footing width is the major parameter that is represented in this paper.

\section{Experimental Testing Program}

\subsection{Sand Box Testing Facility and Materials}

A number of model soil-footing-non-yielding wall models were constructed with $1.15 \mathrm{~m}$ high and tested to their maximum loading capacities. The model wall-footing was designed to be a $1 / 3$ scale, which means each model represents 3 $\mathrm{m}$ height wall-footing at prototype size. The model walls were designed in accordance with similitude rules proposed by Iai [10] to ensure that the geometry of the walls, soil properties and strip footing parameters were proportional to prototype-scale model (i.e. field scale). Results of two model walls from this series of tests are presented to demonstrate the influence of the strip footing width (B) on the response of nonyielding wall-footing system to applied vertical stresses. Figure 1 shows a typical nonyielding wall-strip footing model test setup. The wall thickness was $7.5 \mathrm{~cm}$, the footing width was selected to be $\mathrm{B}=15 \mathrm{~cm}$ and $20 \mathrm{~cm}$, and the distance between the footing and the wall was selected to be $\mathrm{a}=3 \mathrm{~B}$.

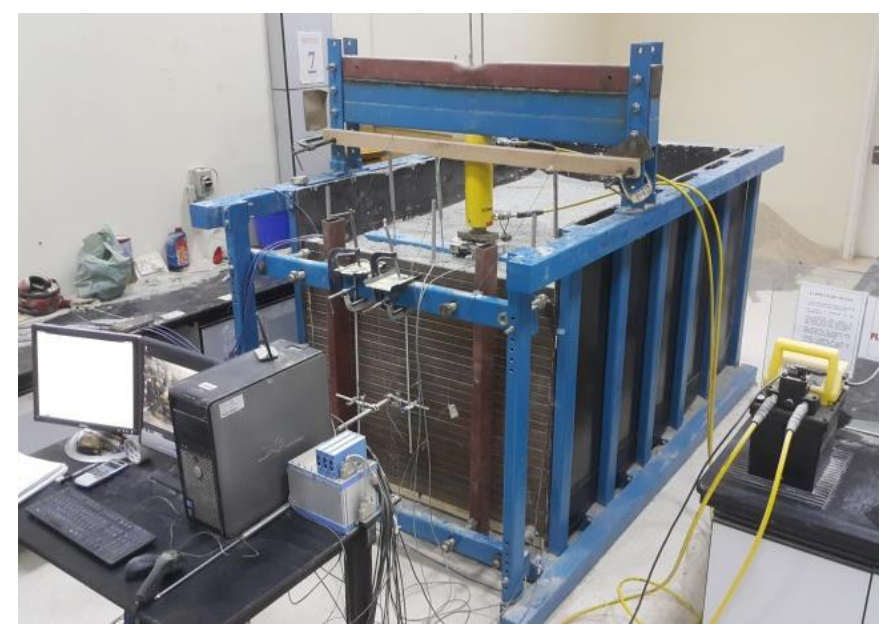

a) Nonyielding wall-strip footing model

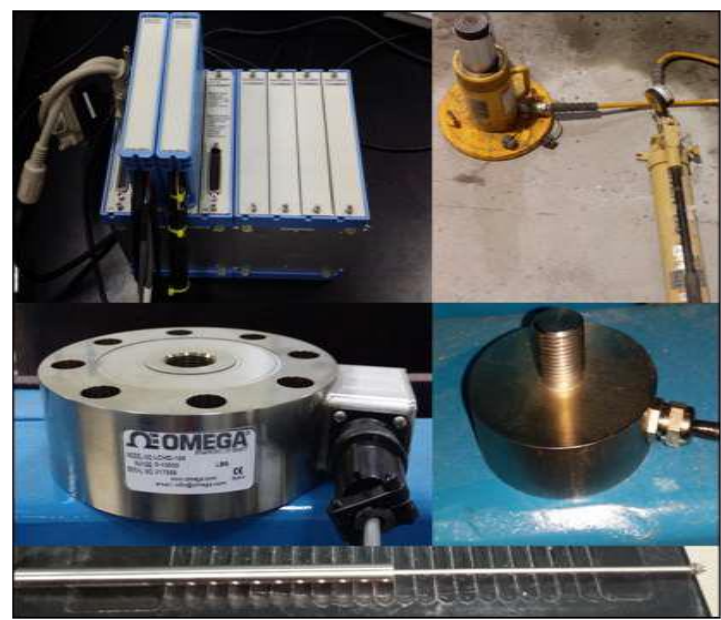

b) Instrumentation types used in the experimental tests Fig. 1: 1/3 Nonyielding wall-strip footing model and instrumentations.

The backfill material used in the model tests was acquired locally from Ras Al-Khaimah Quarry, UAE. According to the Unified Soil Classification System (USCS), the sand was classified as well graded sand (SW), with angular to sub-angular particles. This sand was selected because it is locally available and used with many local construction 
projects. The sand had a maximum dry unit weight of $17.9 \mathrm{kN} / \mathrm{m}^{3}$ at Optimum Moisture Content of 5.5\%. Direct shear tests on the sand prepared to the same unit weight gave a peak direct shear friction angle $\phi=49^{\circ}$. The wall facing was constructed from 23 hollow steel box-sections bolted together with 3-20 mm diameter steel rods to form a $1.15 \mathrm{~m}$ height rigid panel. The strip footing was made of rigid wood plate of $136 \mathrm{~cm}$ length (representing the width of the steel box) and different width $\mathrm{B}=15,20$, and $25 \mathrm{~cm}$. The wooden plate is reinforced with two- $10 \mathrm{~cm}$ by $10 \mathrm{~cm}$ cross section steel beams welded together. A sand layer was glued to the bottom face of the wooden plate (i.e. the face in contact with the soil) in an effort to reduce slippage between the footing and the sand (see Fig. 1).

\subsection{Instrumentations and Applied Vertical Stresses}

Several components were considered in order to design an effective instrumentation and data acquisition system for experimental tests. The instruNet i400 consists of four different card cages; which are easily plugged into a 4-slot card cage that communicates with Windows 7 computer via USB 2.0 is the used data acquisition. Through the plugged cards LVDT and Load Cells were directly connected, as shown in Fig. 1. InstruNet was used because of its high-accuracy data acquisition system in performing low level measurements (e.g. $\pm 100 \mathrm{mV}$ ). The low-level measurements from sensors necessitate accurate measurements with high sampling rates. A high sampling rate is essential to avoid data negligence and to capture the peak values of wall response during loading.

Up to 16 pieces of instrumentation were used in each model wall-footing system. The wall horizontal deflection was measured using a Linear Voltage Displacement Transducer (LVDT) that was mounted against the mid height of the wall. Three vibrating wire transducers pressure cells were used to measure the lateral soil pressure at the back of the wall during loading stages. Two vertical and two horizontal load cells were installed at the base of the wall to measure the forces transmitted to the footing (wall toe). In addition, two-horizontal load cells were installed at the top of the wall facing to measure the force transmitted to the top. The strip footing was instrumented with two load cells, inserted between the footing and the hydraulic actuator, to measure the vertical load applied at the footing. In addition, three LVDTs were attached to a rigid wooden beam above the strip footing to measure the vertical settlements at three locations of the strip footing (Center, left side and right side). Finally, InstruNet World Software was utilized to collect data from all sensors using the data acquisition and a fast PC.
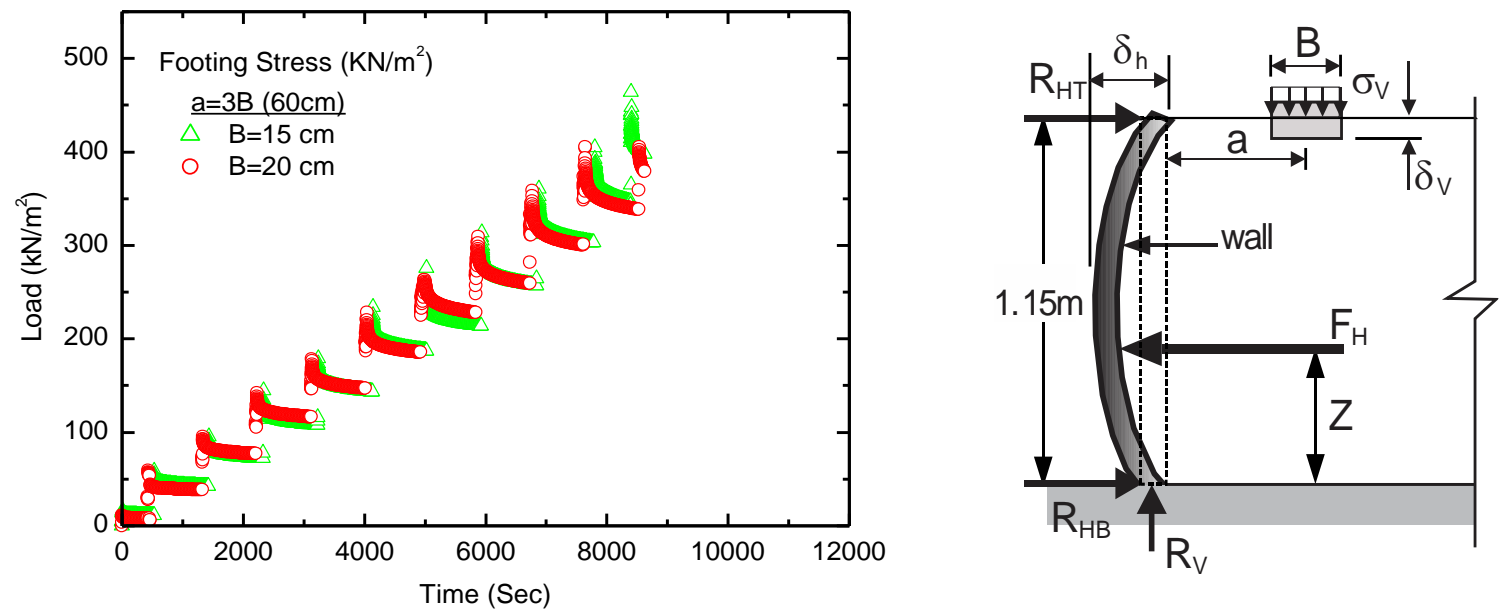

a) Footing vertical stress loading history

b) Schematic of the wall-footing responses

Fig. 2: Schematic of the responses measured during the tests, and Footing vertical stress increments versus time for two model tests

The vertical stress was applied on the strip footing as stepped-stress increments, as shown in Fig. 2a. Figure $2 b$ is a schematic showing wall-footing model responses that mentored during vertical stress applications. This shows that each strip footing was subjected to approximately the same vertical stress-time history. Each stress increment $\left(\Delta \sigma_{\mathrm{v}}\right)$ is held for 15 minutes before applying the next stress increment $[11,12]$. The vertical stress increased until the model failed due to large footing vertical settlement (i.e. $\delta \mathrm{v}=0.1 \mathrm{~B}$ ) or large wall horizontal deflection or both. Loading sequences and 
procedures are applied to follow the Plate Load Test (PLT) standards [12]. In some cases, tests were ended when the ratio of load increment to settlement increment reached minimum [12]. In other cases of excessive horizontal wall deflection, the tests were stopped to maintain the integrity of the wall. Figure $2 b$ also showed the hydraulic actuator performance and its capability to reproduce the applied vertical stress records, which were evaluated during the preliminary stage of the testing program.

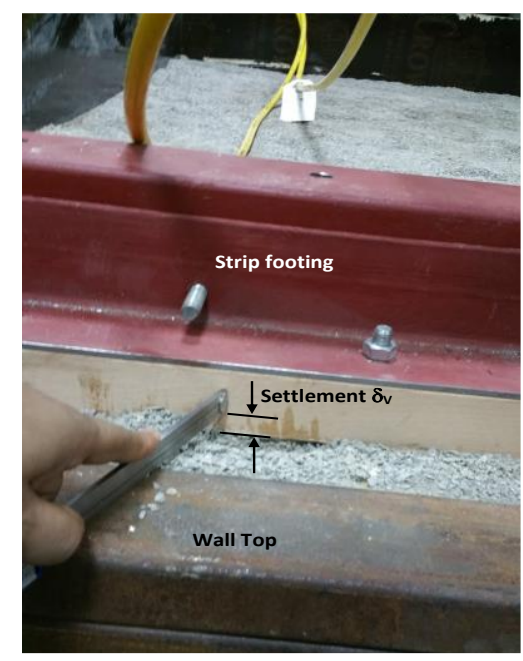

a) Actual Strip Footing Settlement

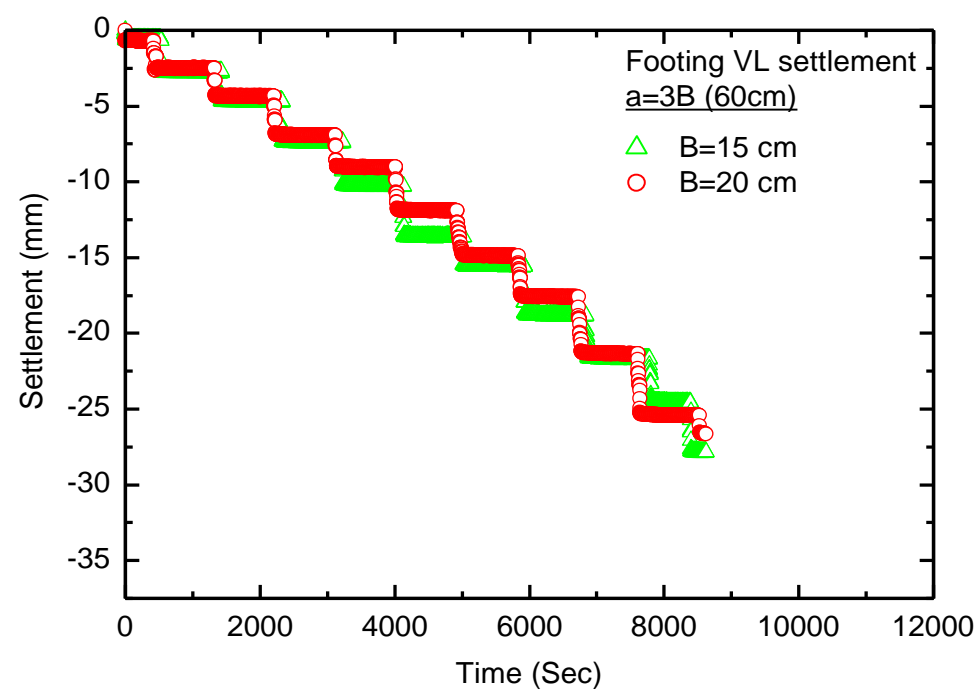

b) Footing vertical settlement history Fig. 3: Footing vertical settlement increment versus time for models 5 and 6.

\section{Results and Discussion}

\subsection{Strip Footing Vertical Stress and Settlement}

In this paper, time histories of the measured responses for two model tests (models 5 and 6) are presented as typical results of the measured responses of all model tests. Models 5 and 6 were constructed with footing width $\mathrm{B}=$ $20 \mathrm{~cm}$ and $15 \mathrm{~cm}$, respectively, and at equal distances from the centreline of the strip footing to the wall, $\mathrm{a}=3 \mathrm{~B}$. To have a uniform base of comparison, the applied vertical stresses for each footing versus time increment is shown in Fig. 2b. It is clear that there is perfect agreement between both stress histories until the tenth-time increment. At time increment No. 10 the test for Model 5 was terminated in order to maintain the integrity of the wall due to the excessive wall deflection. This stress difference might be taking into consideration during result comparison in the following sections.

Footing vertical settlement increment for model tests 5 and 6 versus time are shown in Fig. 3b. The actual settlement of a typical footing at the end of loading stage is shown in Fig. 3a. It is clear that the footing vertical settlement increased as the applied vertical stress increment increased for both model tests. Although, the difference in the strip footing settlement is trivial for the same vertical stress increment, the model with smaller footing width (i.e. B $=15 \mathrm{~cm}$ ) started to show larger settlement at stress increment No. 5, until stress increment No. 8. This is against the elastic theory method used for calculating settlement, which indicates that the vertical settlement increases as the footing width increases. At the last vertical stress increment, increment No. 10, the footing with larger width B indicated slightly larger settlement which in agreement with shallow foundation settlement theory. In conclusion, the vertical settlement of the footing is not only a result of the vertical stress increments, but also affected by the latera; deflection of the retaining wall system.

\subsection{Nonyielding Wall Force Responses}

Vertical forces $\left(\mathrm{R}_{\mathrm{v}}\right)$ acting at the bottom (foundation) of the non-yielding wall are shown in Fig. 4 for model walls 5 and 6. This load is developed due to the application of the vertical stress at the top of the strip footing. At the same vertical stress, the strip footing with larger width (i.e. $B=20 \mathrm{~cm}$ ) imposed larger vertical stress at the back of the wall, 
which is reflected on the vertical force measured at the wall footing. This could be attributed to the volume of soil affected by the strip footing. Figure 5 shows that the volume of soil affected by the footing increased as the footing width increased, at the same vertical stress increment. It is well understood that the vertical force developed at the wall footing is related to the friction between the soil and the wall. As the volume of soil moved under the strip footing increased, the friction force at the wall-backfill interface increased, which led to an increase in the vertical force $\mathrm{R}_{\mathrm{V}}$. It should be noted that these vertical forces is in addition to the self-weight of the wall $\mathrm{W}_{\mathrm{w}}=1.3 \mathrm{KN} / \mathrm{m}$.

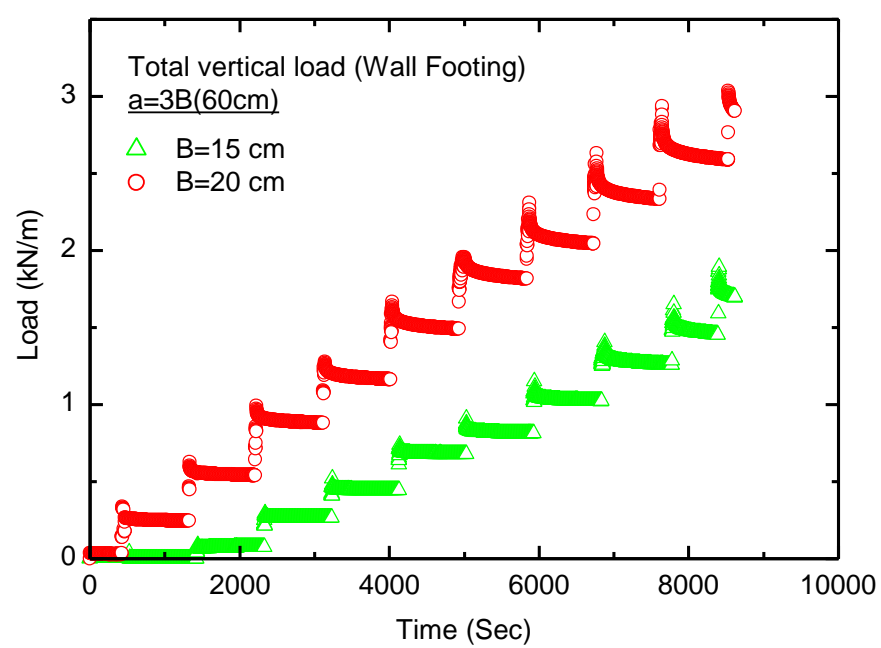

Fig. 4: Vertical load $\left(\mathrm{R}_{\mathrm{V}}\right)$ at the wall footing versus time for models 5 and 6.

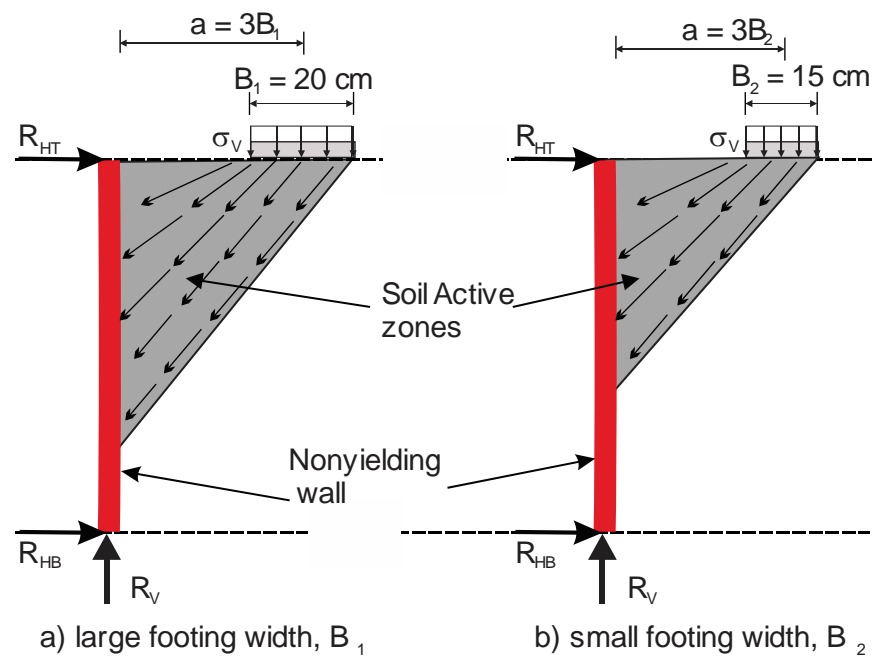

Fig. 5: Sizes of soil shear zones with footing sizes.

Horizontal forces $\left(\mathrm{R}_{\mathrm{H}}\right)$ developed at the bottom (foundation) of the nonyielding wall are shown in Fig. 6 for models 5 and 6. These forces are developed due to the application of vertical stresses at the top of the strip footings, in addition to the at rest lateral earth pressure resulted from the soil self-weight. It is obvious that the strip footing with larger width, model 5 (i.e. $\mathrm{B}=20 \mathrm{~cm}$ ) imposed larger horizontal force $\left(\mathrm{F}_{\mathrm{H}}\right)$ at the back of the wall. This is due to the resultant vertical applied load at each meter length of the strip footing, which is larger for larger strip footing. Despite the near equal vertical stress $\left(\sigma_{\mathrm{V}}\right)$ applied at both strip footings, the footing with larger width B resulted in larger vertical load per each meter length of the wall. This produced larger lateral pressure at the back of the wall, and therefore larger horizontal forces FH. This is in agreement with theoretical solution proposed by Jarquio [13] which produced an increase of the lateral earth pressure caused by strip surface load due to the increase of the footing width. 


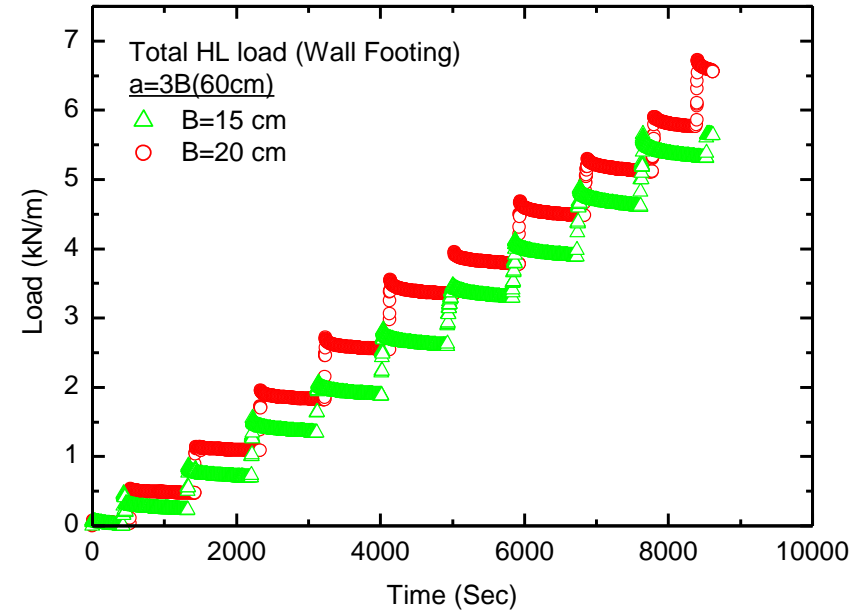

Fig. 6: Horizontal forces (FH) developed at the back of the wall versus time for models 5 and 6.

\subsection{Nonyielding Wall lateral Deflection}

Figure 7a shows an example of laterally deflected typical wall at the end of the test, and Fig. 7b showed the lateral deflection $\left(\delta_{\mathrm{h}}\right)$ measured at the med-height of the nonyielding wall versus time for model tests 5 and 6 . For both models the lateral deflection increased as the vertical stress over strip footing increased. In addition, the strip footing with larger width (i.e. $B=20 \mathrm{~cm}$ ) resulted larger lateral deflection on the wall, despite the coinciding vertical stress increments, compared to the model with small strip footing width (i.e. $\mathrm{B}=15 \mathrm{~cm}$ ). This is expected and attributed to the larger horizontal forces developed at the back of the wall supporting the strip footing with larger width (see Fig. 6).

\subsection{Location of Horizontal Wall Force Resultant}

Figure 8 shows the effect of strip footing width on the location of the lateral earth force at different vertical stresses increments applied at the top of the strip footing. For the footings constructed at distance $\mathrm{a}=3 \mathrm{~B}$, the location at the early stress stage (i.e. small vertical stress increment) is closer to the top of the wall (above $0.7 \mathrm{H}$ from the base), and started to move downward as the footing applied stress increased. This could be interpreted with the help of Fig. 5, which shows the volume of soil active zone. At small applied stress increment it is expected that the volume of active soil zone is small, and therefore, the resultant lateral force is acting closer to the top of the wall. As the stress increment increased, the volume of soil active zone increased and therefore, the resultant lateral earth force moved downward. As for the effect of footing width, Figure 8 indicates that as the footing width decreases, the location of the lateral earth force above the base increases. (i.e. footing with $B=15 \mathrm{~cm}$ gave higher location than footing with $\mathrm{B}=20$ $\mathrm{cm})$. In another words, the location of the earth force resultant above the wall foundation moves towards the top as both footing width and stress increment decreased.

Figure 8 also indicates that the location of the resultant earth force above the wall foundation $(\mathrm{Z})$ stayed constant at $\mathrm{Z}=0.7 \mathrm{H}$ as time $\mathrm{t}=5000 \mathrm{~s}$, which corresponding to a total applied stress $\sigma_{\mathrm{v}}=200 \mathrm{KN} / \mathrm{m}^{2}$, for footing with smaller width. For larger width footing, the value of $\mathrm{Z}$ reached a constant value of $0.5 \mathrm{H}$ at time $\mathrm{t}=3000 \mathrm{~s}$, which corresponding to a total applied stress $\sigma_{\mathrm{v}}=150 \mathrm{KN} / \mathrm{m} 2$. This means that the shape of the distribution of the lateral earth pressure at the back of the non-yielding wall did not change once the strip footing vertical stress reached a threshold value until the ultimate load capacity of the footing. Finally, regardless of the footing width (B), the location (Z) ranged between $0.5 \mathrm{H}$ to $0.7 \mathrm{H}$, which is way above the $0.33 \mathrm{H}$ assumed by the triangular distribution shape. 


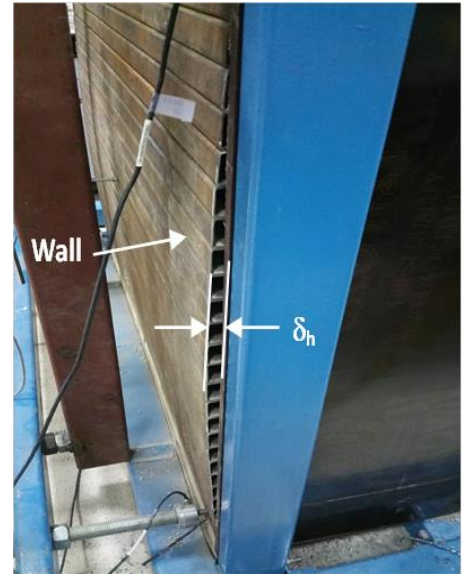

a) Actual Wall Deflection

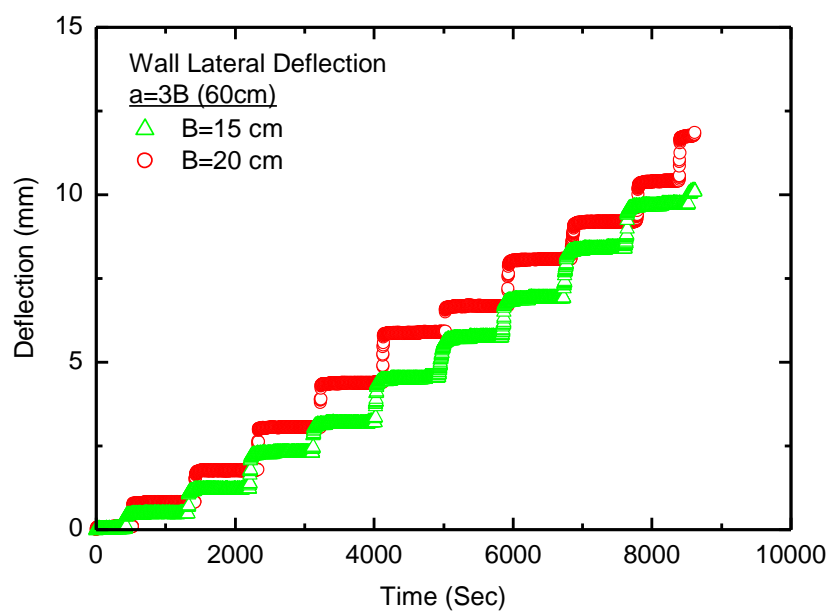

b) Wall Horizontal Deflection History

Fig. 7: Lateral deflection of the wall $(\delta \mathrm{h})$ versus time.

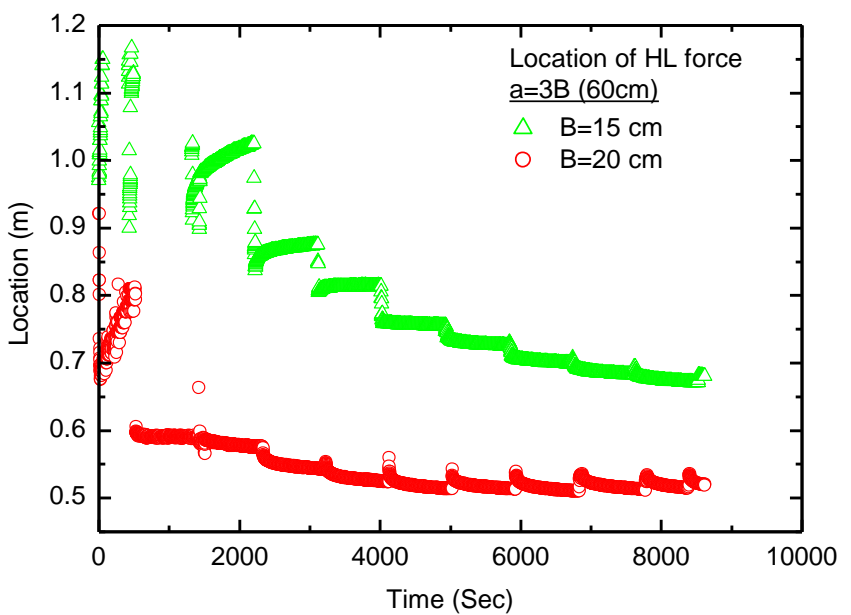

Fig. 8: Location of Horizontal Force

\section{Conclusion}

A large number of wall-foundation systems were experimentally tested and analysed. In this study, results of two wallfooting system models with different footing width, but similar footing distance from the wall are presented and discussed. The results were presented in the form of time histories of foundation settlement, wall lateral force and deflection, vertical forces, and location of lateral forces. Important conclusion and practical considerations are summarised below.

1.Strip footing settlement increased as the applied vertical stress increment increased.

2.The strip footing width (B) showed minor effect on the vertical settlement for footing located at equal distances from the back of the wall.

3.Strip footing with larger width $(B)$ imposed larger vertical force at the back of the nonyielding wall $\left(\mathrm{R}_{\mathrm{V}}\right)$. Neglecting this additional vertical force in the current code of practice might lead to unsafe wall-foundation design output.

4.Strip footing with larger width (B) imposed larger horizontal force $\left(\mathrm{F}_{\mathrm{H}}\right)$ at the back of the wall, despite the equal vertical stress $\left(\sigma_{V}\right)$ applied both strip footings. This force should be practically considered in designing the wall.

5.Nonyielding wall lateral deflection increases with the vertical stress applied by the strip footing, and with the strip footing width. 


\section{Acknowledgements}

The authors would like to acknowledge the financial support provided by the American University of Sharjah through faculty research grant number FRG14-II-19, awarded to Dr. El-Emam.

\section{References}

[1] J. Jaky, "The coefficient of earth pressure at rest," Journal for Society of Hungarian Architects and Engineers, pp.355-358, 1944.

[2] A. Hanna, and R. Al-Romhein, "At-Rest Earth Pressure of Overconsolidated Cohesionless Soil," Journal of Geotechnical and Geo-environmental Engineering ASCE, vol. 134, no. 3, pp. 408-412, 2008.

[3] P. Mayne, and F. Kulhawy, "K $\mathrm{K}_{\mathrm{o}}$-OCR relationships in soil," Journal of the Geotechnical Engineering Division ASCE, vol. 108, no. GT6, pp. 851-872, 1982.

[4] M. M. Sherif, R.D. Mackey, "Pressure on the Retaining Wall with Repeated Loading," Journal of Geotechnical Engineering Division, ASCE, vol. 103, no. GT11, November, 1997. pp. 1341-1345, 1977.

[5] M. El-Emam, "Experimental and numerical study of at-rest lateral earth pressure of over-consolidated sand," Advances in Civil Engineering, vol. 12, 2011.

[6] P. V. Berg, "Effect of surface loading behind earth retaining walls," Delft Geotechnics, vol.2, pp. 767-771, 1991.

[7] S. Rehnman, and B. Broms, "Lateral Pressures on Basement Wall. Results from Full-Scale Tests," 5 ${ }^{\text {th }}$ European Conference on Soil Mechanics and Foundation Engineering, pp. 189-197, 1972.

[8] T. Dave, and S. Dasaka, "Transition of earth pressure on rigid retaining walls subjected to surcharge loading," International Journal of Geotechnical Engineering, vol. 2012, no. 6, pp. 427-435, 2012.

[9] Y. Fang, S. Tzeng and T. Chen, "Earth pressure on an unyielding wall due to a strip surcharge," International Offshore and Polar engineering conference, Lisbon, pp. 1233-1238, 2007.

[10] S. Iai, "Similitude for shaking table tests on soil-structure-fluid model in $1 \mathrm{~g}$ gravitational field," Soils and Foundations, vol. 29, no. 1, pp. 105-118, 1989.

[11] R. Jalla, "Basement Wall Design: Geotechnical Aspects," Journal of Architectural Engineering, vol. 5, pp. 89-94, 1999.

[12] ASTM, "Standard Test Method for Bearing Capacity of Soil for Static Load and Spread Footings," West Conshohocken, ASTM, 1994.

[13] R. Jarquio, "Total lateral surcharge pressure due to strip load," J. of the Geotechnical Engineering Div. ASCE, vol. 107, no. 10, pp. 1424-1428, 1981. 